\title{
The need for boundary adjustments in the proposed Hong Kong Title Registration Bill
}

\author{
by M M Park \\ Graduate student \\ Department of Geomatics, The University of Melbourne \\ and I P Williamson \\ Professor of Surveying and Land Information \\ Department of Geomatics, The University of Melbourne
}

\section{ABSTRACT}

The proposed Hong Kong Land Title Registration system does not include provisions for the variation in boundary location or remedying any discrepancies in the boundary locations of a land parcel. The practicalities of land administration require some means of boundary adjustment (or repair) in any land system, including registered title. This is so notwithstanding that there appears to be an inherent contradiction in allowing one of the possible mechanisms (part parcel adverse possession) in a registered title system. This paper argues that a modern LIS (including the proposed Hong Kong registered land system) should include such a mechanism. It is even suggested that failure to provide for boundary repair merely postpones the inevitable adoption of such provisions. Of the possible mechanisms it is concluded that an alternative to adverse possession, statutory encroachment, is preferable to part parcel adverse possession. A further suggestion is that provisions for statutory encroachment be included within the proposed HK Title Registration Bill with the proviso that the provision be repealed if left unused.

\section{INTRODUCTION}

Experience throughout a number of jurisdictions utilizing registered land title indicates the need for some mechanism wherein small adjustments in the location of the boundary should be permitted. Pursuant to the law of real property inherited by the common law jurisdictions from England this has been mostly provided for by extending the principles of adverse possession to part only of a land parcel. An alternative means of providing for such adjustment is that of statutory encroachment wherein a specialized adjudicator is empowered with wide discretionary powers to resolve disputes involving small encroachments across a boundary into the adjoining lot. This paper suggests that the new Hong Kong Land Title Registration legislation is deficient because it fails to address the issue of boundary location discrepancies and provide some simple mechanism for resolving the problems arising from such discrepancies. Similarly deficient are those other jurisdictions which do not allow for such boundary repair procedures such as the Australian Capital Territory and the recently adopted Singaporean registered land title legislation. Also included are those jurisdictions such as England and Tasmania which, while not prohibiting such boundary repair, impose burdensome restrictions so as to severely limit the availability of the remedy.

\section{THE NEED FOR A REPAIR MECHANISM}

\subsection{The extent of the issue}

Differences between true (de jure) and occupational (de facto) boundaries are well recognised in the literature (Dale 1976, 22-23; Dale and McLaughlin 1999, 51). Similarly the prevalence of such discrepancies is also well recognised (Simpson 1976, 141-142; Dale 1976, 22-23; Wallace 1994). Dowson and Sheppard $(1952,81)$ estimated that five per cent of land parcels can be expected to change materially in outline, shape, and area annually. These changes do not give rise to the compensation provisions of the registered land title schemes as the assurance fund do not compensate for the loss of a land parcel through adverse possession even where the loss is occasioned by reliance 
upon the register. Further, the assurance fund does not "guarantee" against shortfalls in the actual area or dimensions being wrongly shown in the register or the certificate of title (Sim 1971, 141-142).

With few exceptions most of the jurisdictions utilizing land title registration have included some means of adjusting or "repairing" the boundaries of a land holding. Notable exceptions are the Australian Capital Territory and the city-state of Singapore. It is currently proposed that Hong Kong will also dispense with adverse possession (including part parcel adverse possession). It may well be that these small and highly developed affluent jurisdictions are better able to utilise modern surveying techniques to the extent that such boundary discrepancies do not arise or arise less often.

In evidence before the Tasmanian Law Reform Commissioner in 1994 (LRCT 1995, p 22), that States's Recorder indicated that 1 in 20 properties in Hobart have problems associated with their boundaries while the 1998 Victorian Parliamentary Law Reform Committee received evidence from the Land Registry that of approximately a half million dealings per annum in the late 1990s, there were some eighty (or so) for part parcel adverse possession applications (VPLRC 1998, 143).

A possible qualification to the Victorian experience is that the law in force does not necessarily require an application to finalise or complete acquisition of land, that is, there may be many more instances that have not yet been brought to the attention of the Registry because there is no compulsion to notify the Registry and, furthermore, some instances may involve affected persons (occupiers of the abutting parcels) remaining unaware of the existence of a discrepancy in the boundary location.

An added complication arising from the Victorian Land Registry figures is that the law operating in Victoria does not require the adverse occupier to apply to be entered upon the register. Consequently a proprietor whose land has been encroached upon is unable to apply in their own right to "shake off" that portion of their land to which their title has been extinguished (ibid 148). It follows that there are instances of successful acquisition of title by adverse possession which are not necessarily known to the registry office or not known at this time.

The suggested benefit flowing to the Victorian community is that check surveys are rarely undertaken, unlike in New South Wales where "a check survey is virtually mandatory for a purchase of property" adding at least several hundred dollars to the cost of conveyancing (Registrar of Titles, Submission Number 21 dated 13 March 1998, ibid Appendix A). This conclusion was in accord with an earlier conclusion of the Law Reform Commission of Victoria in its 1987 report (LRCV 1987, 10).

The two alternative remedies are described by Simpson $(1976,155)$ : the rule of adverse possession is of great practical convenience permitting the acceptance of the boundary as it appears on the ground without obtaining a possibly expensive expert survey corroboration that the boundary corresponds exactly with that shown on the registry plan. This is "what you see is what you get" (WYSIWYG) (Barrie 1976, 257; Wallace 1994; Ruoff 1957, 38). Wallace writes of "repair" as a secondary function of possessory titles and adverse possession. Otherwise the prudent purchaser may possibly incur further expense in calling for a competent boundary or title survey to show that what he or she sees on the ground is in accord exactly with the plan. The "considerable expense" is an added transaction cost that may well inhibit the land market. It is clear that Simpson favours the advantage of long-term occupation supported by adverse possession with regard to boundary variations.

The other approach is to rely on an accurate survey (Davis 1971, 92), a solution also made in an earlier edition of the Davis text that was dismissed as "complacent" by Simpson (ibid 156). That the advice regarding accurate surveys remained in the second edition (published after New Zealand introduced the partial concessions in favour of adverse possession in 1963) shows the necessity of an accurate survey where the introduction of adverse possession in that jurisdiction was restricted to whole parcels 
only. This is required where there is no recognition accorded to occupational boundaries where they differ from the true boundary.

The UK Law Commission has recently recognised the role of adverse possession in rectifying misplaced boundaries as has the most recent edition of a leading English real property text (Megarry and Wade 2000, 235-236). The 1998 Law Commission report asserts that "most cases of adverse possession are in fact boundary disputes" (Law Commission 1998, \ 10.15).

It may be that the best argument favouring occupational boundaries over true legal boundaries is the immense practical difficulties of restoring the true legal boundaries, for example, in the Brisbane subdivision referred to by McClelland (2001) involving "serial" encroachments where all the lot boundaries in the sub-division are displaced horizontally. This pragmatic argument is the one least advanced in support of part parcel adverse possession yet may well be the only tenable rationale.

It is instructive to note that the legislature of Saskatchewan has not acted upon the recommendation of that province's Law Reform Commission which concluded that the importance of possession as a basis for title had been eroded since the introduction of title registration and that the notion that possession can create an interest in land ought to be abandoned (LRCS 1989, 25).

\subsection{How important an issue?}

Summarising the submissions received by it, the Victorian Parliamentary Law Reform Committee made the observation that boundary fence disagreements make a significant category of neighbourhood disputes which are highly charged, emotional, and angry and lead to acrimonious and prolonged litigation (VPLRC ibid, 127).

Another means of assessing the extent of the problem is the importance attached to it by the community. A legal issue that may only directly affect very few members of the community may inflame the passion of those unaffected members. In 1994 there arose much public disquiet in Tasmania following upon the decision handed down in Woodward v Hazell (1994). The public disquiet extended beyond Tasmania because of nationwide television coverage by current affairs television broadcasts with the consequence that the NSW Land Titles Office was subjected to enquiries from landholders seeking reassurance with regard to adverse possession in that state. Echoes of the Tasmanian case surfaced in Western Australia in 2000 when evidence of the concern it engendered in a Western Australian land holder was before the court in Holdsworth v Holdsworth (2001). The public disquiet in Tasmania saw the establishment of a Law Reform Commissioner's inquiry into adverse possession. The Commissioner's report included several proposals to amend the law which culminated in the 2001 amendments effecting major changes to the law of adverse possession in that state (LRCT 1995).

In the United Kingdom, the Law Commission reports record "hostile public criticism" $(1988,24)$, "growing public disquiet" $(2001,30)$, and "considerable public disquiet" $(2001,301)$ with regard to adverse possession, both whole parcel and part parcel.

The conclusion is drawn that the extent of the problem is small in the number of persons affected but large in the amount of heat generated.

\section{AN OPPOSING VIEW}

Another mode of resolving the boundary location discrepancy problem is to leave well enough alone, that is to refuse to recognise any but the true and correct boundary. Where the occupational boundary does not coincide with the correct location then it must be relocated to conform. Such a mode does not allow for flexibility when the issue arises and may impose an unreasonably disproportionate burden upon some or all the parties affected. Providing a means of resolution in advance of the problem 
arising is akin to the proverbial desirability of erecting a fence at the top of the cliff rather than stationing an ambulance at the bottom. The preference for the fence over the ambulance should find favour with all but the community's litigation lawyers otherwise referred to as ambulance chasers.

\section{ORIGIN OF THE DISCREPANCY}

The history of such boundary location discrepancies in the Australian jurisdictions owes much to poor surveying techniques in the nineteenth century (Arter 1960-61, 112). However, the source of the discrepancy is mostly irrelevant. If there is a discrepancy the problem requires resolution although it is may be necessary to attribute cause or fault in seeking to tailor a suitable solution.

Primarily, the cause may be attributed to a mistake or blunder or negligence on the part of a professional surveyor charged with the responsibility of setting out (on the ground) the boundary of the land holding. This is particularly prevalent with regard to surveys undertaken many years ago where the technical qualifications and standards were lacking and the then available techniques have since been much improved. Other sources may be attributed to careless builders and others dislodging correctly located survey markers and proceeding further without appreciating the need for the proper re-establishing of the location. That a jurisdiction does not permit a 'repair' mechanism does not of itself preclude the necessity arising. For example, while for many years Queensland did not permit any variation from the "correct" boundary location, this did not prevent the arising of major discrepancies in a sub-division located in Brisbane (McClelland 2001).

The discrepancy does not necessarily arise from inaccurate older surveying practices and techniques. The Victorian Committee considered the increasing risk of encroachment arising from the modern practice of creating title prior to the building of multi-density developments ("off the plan" strata title sales) wherein advantages accrue to both the developer and the purchasers (VPLRC 1998, 125). This prompted the Committee to recommend that consideration be given to the adoption of legislation in Victoria similar to that of the NSW Encroachment of Buildings Act 1922.

In New South Wales, the long-standing prohibition against adverse possession of registered title land prompted this judicial dictum from Justice Harvey in a lawsuit involving a disputed boundary location:

It is to my mind one of the great flaws in the system of the Real Property Act that there is no provision analogous to the Statute of Limitations by which long-continued possession crystallises a title. The result under the Real Property Act is this, that if at any length of time you can get a sufficient number of surveyors sufficiently positive to come and make a case to the Court to re-establish old surveys, no matter how long and how uninterrupted the possession may be, the Court may have to tell the proprietor, "You have been in possession of the wrong land all these years, and you have not got a title by possession because the Act does not allow you to have a title by possession."

$$
\text { Turner v Myerson (1917) } 18 \text { SR(NSW) 133, at } 136 .
$$

Although the issue of whole parcel adverse possession was not addressed for another six decades, the NSW legislature shortly thereafter enacted the Encroachment of Buildings Act 1922. This statute provided limited relief to the inadvertent trespasser who has unknowingly erected a building or other valuable improvement in a way that encroached upon an adjoining owner's land parcel. The relief was not founded upon adverse possession and was designed to permit a fair and just solution to such inadvertent encroachments.

The motivation of the legislature may be inferred from the Parliamentary Debates wherein the Attorney-General made reference to inadvertent encroachments and the evil that was associated with the encroached upon neighbour determination to "gouge" or exploit the trespasser's inadvertence. The Attorney provided examples in the Sydney suburbs of Arncliffe and Balmain where in each instance, a one inch encroachment over land valued at one or two pounds per foot was the subject of a demand of 
one hundred pounds, that is, a rate of twelve hundred pounds per foot (NSW Legislative Council, Parliamentary Debates, 1 December, 1922, $2287 \mathrm{ff}$ ). Similar examples occurring in Five Dock, Sydney, Drummoyne, and Redfern were provided with the Honourable J H Wise commenting that "the measure had been absolutely necessary for years past" (ibid 2293),

The persuasiveness of the debate is however called into question by the Attorney's assertion that New Zealand had passed a similar Act in 1908, and that Victoria had a somewhat similar law in force that "works very well". Victoria has never enacted a statute providing for 'statutory encroachment' and New Zealand only introduced its encroachment provisions in 1952. The NSW 1922 Act provided the relief sought without permitting adverse possession of registered title land.

Other jurisdictions which did not accord recognition to the acquisition of title by adverse possession were moved to introduce similar legislation to that of NSW: South Australia in 1944, the Northern Territory in 1945, New Zealand in 1952, and Queensland in 1955. Additionally Western Australia and Alberta provided similar provisions (in addition to permitting part parcel adverse possession). The purpose of the legislation was to confer jurisdiction on the courts in cases of inadvertent encroachment to ameliorate the only remedy available under common law - demolition of the offending encroachment.

Thus it may be concluded, with the exception of the Australian Capital Territory and (since 2001) Tasmania, all Australian jurisdictions have passed legislation allowing for adjustment or repair of erroneously located boundaries by way of statutory encroachment or part parcel adverse possession or both.

\section{THE PLACE OF ADVERSE POSSESSION IN BOUNDARY DISCREPANCIES.}

Little has been written regarding adverse possession of part only of a parcel. Thus the variation of boundaries associated with part parcel adverse possession has been dealt with, if at all, as within adverse possession generally. See, for example, Powell-Smith $(1975,15)$ where he observed that "[b]oundaries are frequently varied in this way by minor encroachments upon neighbouring property, often when walls are rebuilt or wooden fences re-erected.” Halsbury's Laws of England (1992, \909 at pp 397-398) restricts itself to a passing comment; possibly because adverse possession of less than a single whole parcel was not fully recognised until as recently as 1833 . Prior to the 1833 law reforms, occupation or possession of less than the whole land holding was deemed to be occupation of the whole where the remainder of the holding was not occupied. Since the 1833 reforms this is no longer the case.

The modern law of adverse possession arose in the early nineteenth century and can be traced back as far as the reign of Edward I in the thirteenth century. Prior to the law reforms of 1833 adverse possession was only applicable to whole parcels of land and was a means of resolving disputes between the legal heir and an opportunistic usurper. Occupation of part was deemed to be occupation of the whole (constructive occupation). Another way of describing the 1833 reforms would be to suggest that the older forms of adverse possession were concerned with excluding (or shutting out) the rightful owner while the reform allowed for the extruding (or thrusting out or dispossessing) the rightful owner (Torrens 1881, 23). The first involves preventing a rightful owner from entering into possession while the latter involves the eviction of the rightful owner after that owner has entered into possession. Lord Plumer in determining a law case in 1820 (before the 1833 reforms) concluded that "[t]he individual hardship will, upon the whole, be less by withholding from one who has slept upon his right, and never yet possessed it, than to take away from the other what he has long been allowed to consider as his own, ..." (Cholmondeley (Marquis) v Lord Clinton 1820). Thus it is suggested that part parcel adverse possession has only arisen since the 1833 reforms to the law of real property. Part parcel adverse possession was but an extension to the existing law of adverse possession (of the whole parcel). 


\section{THE PLACE OF ADVERSE POSSESSION IN A REGISTERED TITLE SYSTEM}

There exists a general perception that the principles pertaining to adverse possession cannot be incorporated within a registered title system without abandoning logic. As a consequence there are many jurisdictions that do not permit adverse possession to operate within their registered title systems. For example, with the exception of Alberta, all the Canadian registered land title provinces do not allow adverse possession. The United States jurisdictions which have adopted registered title also do not permit adverse possession of registered title land and in the last decade Singapore and Malaysia have abolished adverse possession from their registered land title systems. The Australian experience, with the exception of Victoria, Western Australia, and Tasmania, has been the prohibition of adverse possession with its recent acceptance in a restricted form to provide security of tenure in instances of abandoned land and disappeared registered proprietors.

Adverse possession involves the recognition of undocumented property rights founded upon long-term occupation or possession. Opposed to this is the underlying principle of title registration wherein all property rights are recorded (or documented) in the register. Another way of describing the conflict is that possession is strong evidence which supports an inference of ownership while registration is considered to be the ultimate evidence of ownership. This conflict arises because there are two principles of real property law that are seemingly in opposition. These are, that the title holder is deemed to be in possession of the property in the absence of any evidence to the contrary (Powell $\mathrm{v}$ McFarlane 1977, 470), and possession is good evidence of title in the absence of evidence to the contrary (Jackson 1967, 11 ff; Megarry and Wade 1975, 1004 ff; Sackville and Neave 1975, 84 ff). The conflict arises when the titleholder and the possessor are not the same person. However, the resolution is not difficult; it only being necessary to determine which of the two principles should prevail. Where there is a limitation period, the titleholder prevails over the possessor where that period has not passed and, when it has passed, the position is reversed such that the possessor prevails over the titleholder.

The conflict may be further exacerbated in the case of registered title land where the public register is the central depository of title information. That the central register comprehensively and correctly reflects the current status of the title and that a trespasser can acquire title through long continued adverse occupation are in opposition when the acquired title based upon possession is an overriding interest which binds the proprietor without being entered on the register (Megarry and Wade 1975, Glossary page cxv).

That the register is paramount is "one of the fundamental principles of Torrens' system" which would necessarily be violated by permitting off-register overriding proprietary interests to be upheld (Dowson and Sheppard 1956, 131; Davis 1971, 44). There is an inherent conflict between a title registration scheme that purports to disclose all property interests in the register and the recognition of undisclosed off-register overriding interests that prevail over the interests of the registered proprietor notwithstanding the indefeasibility provisions of the registered title systems. However, this is not the case in those jurisdictions that accord recognition of title based upon adverse possession only if such title is registered. Such a title is not an undisclosed off-register title. Such a title is disclosed upon inspection of the register.

In summary, it is concluded that it is necessary to require registration of title irrespective of the manner of acquisition of title, and, where title is accorded recognition without registration, that is the possessory title overrides the registered title; such a system can only be described as a quasi-title registration system. The system currently in force in Victoria and Western Australia are thus quasititle registration systems. Thus it follows that the conflict between adverse possession and registered title is apparent only and consequently is merely a paradox. There is no conflict between the two 
where the title founded upon adverse possession is required to be registered before it is accorded legal recognition.

Thus it is suggested that there is no impediment to the incorporation of part parcel adverse possession into a registered land system as a means of resolution of boundary location problems so long as the land so acquired be entered into the register. Failure to register is failure to acquire.

\section{ALTERNATES TO PART PARCEL ADVERSE POSSESSION 8.1 Statutory alternative - encroachment}

Predating the introduction of registration of land title there was accorded some legal recognition of real property rights founded upon informal and irregular occupation. De Soto (2000, 105-140 and 1501) describes those rights gained by the North American pioneer settlers who took up land holdings outside and ahead of the advancing jurisdiction of the then governments. That is, these pioneer settlers occupied land that was not subject to any law at the time of settlement. Later, when government and the reach of law extended into those areas settled by the pioneers it was politically expedient to recognise the long enjoyed informal occupation. In part this recognition was based upon the expenditure of time and effort and money in developing the holding. For the newly established government to deprive the occupier of long standing would in effect be a confiscation of property. The legal recognition of these de facto land holdings applied to whole holdings and provided recognition to established occupiers without the necessity of displacing another landholder or competing claimant. The legal recognition of one landholder was not at the expense of another - this was not the resolution of a dispute between two opposing parties. This recognition of rights acquired by de facto settlement and occupation was likened to the acquisition of property in a wild animal by its taming. Whereas there is no property in a wild animal, property in such an animal vests upon its capture or taming in the person performing the capture or taming.

This recognition of property acquired by the expenditure of effort by the settler and subject to no other claim was later extended to instances where "justice" demanded the recognition of such rights even where there did exist opposing claimants. For example, a mistaken occupation of another's land and the subsequent improvement of that land at the expense of and by the mistaken occupier.

Although there have been instances where a court has provided a remedy between opposing claimants where there has been mistaken occupation, in the main the courts have declined to make such determinations without legislative authority. It is not within the common law making powers of a court to take property, in this case land, from one disputant and award it to another solely on the basis of mistake. Pursuant to statutory authority conferred by the legislature this power may be characterised as "statutory encroachment".

As an alternative to part parcel adverse possession, statutory encroachment has been adopted in many of the jurisdictions that do not permit adverse possession, either whole or part parcel. This involves encroachment across a boundary by an improvement to the bare land parcel. Conversely it is noteworthy that several jurisdictions that do allow part parcel adverse possession also permit statutory encroachment while the Australian Capital Territory permits neither.

The relevant differences are that encroachment does not depend upon the passage of a time period; the court administering the statute is empowered to award compensation to the landholder whose parcel is diminished by the encroachment, the encroachment is required to be more substantial than mere occupation and the court administering the statute is provided with wide discretionary powers to do justice between the parties according to the circumstances of each case. A factor to be considered by the court is a consideration of the circumstances leading up to the building of the encroachment. Thus an honest but mistaken belief in the location of a boundary will be looked upon more favourably than a cavalier disregard and infringement of the proprietary rights of a neighbouring landholder. 
Australasian approaches to encroachments and improvements

As a basis for considering the various Australasian encroachment statutes the Encroachment of Buildings Act 1922 (NSW) is representative. This legislation permits either of the adjoining owners to apply to the court for relief where one owner has erected a building or other improvement of a permanent nature which encroaches onto the adjoining parcel. The range of powers available to the court is wide. The Court can order the demolition of the encroaching structure, payment of compensation by the encroaching owner to the adjoining owner, the conveyance, transfer, or lease of that part of the adjoining owner's land to the encroaching owner, or the grant to the encroaching owner of an easement over the adjoining land. The court is given wide powers and a variety of remedies are available thus allowing the court to do "justice" in all the circumstances of the case before it. Further the court is empowered to award compensation reflecting the "culpability" of the encroaching land owner - compensation is minimal in cases of unintentional encroachments without negligence on the part of the encroaching owner while increased compensation is payable where the encroaching owner is unable to demonstrate lack of intent to encroach or negligence.

Thus the position in regard to the Australian jurisdictions may be summarised as Victoria permitting part parcel adverse possession with no provisions for statutory encroachment, while NSW and the Northern Territory prohibit part parcel adverse possession but allow statutory encroachment. Queensland, South Australia and Western Australia permit both although Queensland and South Australia favour an encroachment application over a part parcel adverse possession application. The Australian Capital Territory permits neither. Tasmania allowed part parcel adverse possession until April 2001 when major amendments to that state's registered land title legislation were passed by the parliament with the effect that it is now discouraged and there is no provision for statutory encroachment. England does not allow for statutory encroachment and permits part parcel adverse possession only in the most limited circumstances since the passage of the Land Registration Act 2002. Prior to the 2002 Act, part parcel adverse possession was permitted to the same extent as it was for unregistered land. Of the Canadian provinces, only Alberta permits both statutory encroachment and part parcel adverse possession while the remaining registered land title provinces, British Columbia, Manitoba, Ontario, and Saskatchewan permit statutory encroachment only. Elsewhere, New Zealand prohibits part parcel adverse possession but does allow statutory encroachment and Singapore permits neither since 1994 when it repealed those provisions permitting adverse possession (including part parcel adverse possession) from its registered land statute.

Statutory encroachment permits either of the parties affected to make application seeking a remedy. This overcomes a perceived disadvantage of part partial adverse possession where only the adverse occupier is empowered to apply and if the occupier declines to do so, the encroached upon proprietor is left with a known and apparent blemish on his or her title which cannot be rectified without the assistance of the adverse occupier.

\subsection{Statutory alternative - presumptions}

Another alternative is the statutory recognition of the de minimis rule ("the law does not concern itself with trifles") where, in Victoria pursuant to the Property Law Act 1958, the dimensions of the boundaries of a land parcel are construed as though the phrase "a little more or less" was appended to the dimension unless expressly negatived: section 272. The section imposes a limit such that a deviation less than the limit will not permit litigation arising from the deviation. The limit is $50 \mathrm{~mm}$ for boundaries of length less than 40.30 metres and a ratio of one in 500 of a boundary of length exceeding 40.30 metres. This provision is not wholly satisfactory in that the bar against litigation is confined to vendor and purchaser and the parties may agree to dispense with the provision. South Australia has a similar provision in its registered title statute permitting the Registrar to make amendments to the register without the need for consulting with the affected parties. The Registrar cannot proceed where the proposed amendments exceed these limits unless the affected parties are 
notified and permitted to make representations. These provisions are not directly relevant to the resolution of discrepancies in boundary location - these provisions are founded upon redefining the possible problem so that it is no longer a problem, the discrepancy being sufficiently small that there does not exist an unacceptable discrepancy.

\subsection{Statutory alternatives - rectification by the Registrar}

Other provisions in the Victorian Transfer of Land Act 1958 permit an application by a proprietor to have the relevant certificate of title amended to show the boundaries on the certificate coincide with the land actually and bona fide ("in good faith") occupied by the proprietor: section 99. Additionally sections 102 and 103 confer upon the Registrar the power to correct entries in the register to rectify boundary discrepancies arising from errors in measurement. These latter powers of correction are not sufficiently wide to encompass the common boundary errors or discrepancies where a boundary fence or building has been mistakenly erected off-boundary. Similar powers of correction are conferred upon the registrars in the other jurisdictions with registered land title schemes.

\section{CONCLUSION}

We conclude that the proposed Hong Kong registered title legislation is deficient in not providing some means of resolving boundary location discrepancies. We offer the suggestion that at the minimum the Hong Kong legislature should include provisions for statutory encroachment within its registered land title statute. If the proponents of the legislation in its current form are correct and there is no need for these provisions, then there should arise no difficulty in their repeal after a sufficient period of disuse demonstrating their superfluous nature. On the other hand, if the need for such provisions does arise, there will be no difficulty in utilizing those already in existence rather than belated amendment to the legislation.

\section{ACKNOWLEDGEMENT}

This paper is a shorter version of and has borrowed substantially from a paper submitted to The Australian Surveyor titled "The need for boundary adjustments" by Park and Williamson (2003).

\section{REFERENCES}

Arter, F W (1960-61) "A review of the Torrens system and some aspects of title survey", Australian Surveyor 18: 108.

Barrie, J K (1976), "Land Registration and Boundary Surveys", Australian Surveyor 28(5): 256.

Cholmondeley (Marquis) v Lord Clinton (1820) 2 Jaq \& W 1; 37 ER 527

Dale, P F (1976), Cadastral surveys within the Commonwealth, London, HMSO.

Dale, P F and J D McLaughlin (1988), Land Information Management: an introduction with special reference to cadastral problems in Third World countries, Oxford, Clarendon Press.

Dale, P F and J D McLaughlin (1999), Land Administration, Oxford, Oxford University Press.

Davis, B H (1971), Kelly's Summary of the law relating to land surveying in New Zealand, 4th ed, Wellington, Hutcheson, Bowman \& Stewart.

de Soto, H (2000), The mystery of capital, New York, Basic Books.

Dowson, E and V L O Sheppard (1952), Land Registration, London, HMSO.

Dowson, E and V L O Sheppard (1956), Land Registration, 2nd ed, London, HMSO.

Halsbury's Laws of England (1992), 4(1)(re-issue), 4th ed, London, Butterworths.

Holdsworth $\mathrm{v}$ Holdsworth [2001] WASC 25

http://www.austlii.edu.au/au/cases/wa/WASC/2001/25.rtf [accessed 19 November, 2002] Jackson, D C (1967), Principles of Property Law, Sydney, Law Book Co.

Kerr, D (1927), The Principles of the Australian Lands Titles (Torrens) System, Sydney, Law Book Co. 
Law Commission and H M Land Registry (1998), Land registration for the Twenty-first century: a consultative document, London, HMSO.

Law Commission and H M Land Registry (2001), Land registration for the Twenty-first century: a conveyancing revolution (Land Registration Bill and Commentary), London, The Stationary Office.

LRCS (1989), Proposals for a new Limitations of Actions Act, Saskatoon, Law Reform Commission of Saskatchewan.

LRCT (1995), Report on Adverse Possession and other possessory claims to land, Hobart, Law Reform Commissioner of Tasmania.

LRCV (1987), The Torrens Register Book, Report No. 12, Melbourne, Law Reform Commission of Victoria.

McClelland, P (2001), "Whatever happened to RP 19673?” The Queensland Surveyor 2001(1): 26-36.

Megarry, R E and H W R Wade (1975), The Law of Real Property, 4th ed, London, Stevens.

Megarry, R E and H W R Wade (2000), The Law of Real Property, 6th ed, London, Stevens.

Powell v McFarlane (1977) 38 P \& CR 452

Powell-Smith, V (1975), The Law of Boundaries and Fences, 2nd ed, London, Butterworths.

Ruoff, T B F (1957), An Englishman looks at the Torrens System, Sydney, Law Book Co.

Sackville, R and M A Neave (1975), Property Law: Cases and Materials, 2nd ed, Sydney, Butterworths.

Sim, P B A (1971), "The compensation provisions of the Act", The New Zealand Torrens System Centennial Essays, (ed G W Hinde), Wellington, Butterworths.

Simpson, S R (1976), Land Law and Registration, London, Cambridge University Press.

Torrens, R (1881), An essay on the transfer of land by registration, London, Cassell.

Turner v Myerson (1917) 18 SR(NSW) 133.

VPLRC (1998), Review of the Fences Act 1968 Report, Melbourne, Parliament of Victoria Law Reform Committee.

Wallace, J (1994), "Principles of the law of possession", Legal Education Seminar: Possession of Titled Land, Melbourne, Leo Cussen Institute.

Woodward v Wesley Hazell P/L [1994] ANZ Conv R 624 http://www.austlii.edu.au/au/cases/tas/supreme_ct/unrep338.html [accessed April 10, 2002] 


\section{University Library}

\section{- M M I E R R A A gateway to Melbourne's research publications}

Minerva Access is the Institutional Repository of The University of Melbourne

Author/s:

Park, M;WILLIAMSON, IP

Title:

The Need for Boundary Adjustments in the Proposed Hong Kong Title Registration Bill

Date:

2003

Citation:

Park, M. \& WILLIAMSON, I. P. (2003). The Need for Boundary Adjustments in the Proposed Hong Kong Title Registration Bill. Journal of Geospatial Engineering, 5 (1), pp.29-38

Publication Status:

Published

Persistent Link:

http://hdl.handle.net/11343/33966 